\title{
Salmonella enterica serovar Enteritidis brain abscess mimicking meningitis after surgery for glioblastoma multiforme: a case report and review of the literature
}

\author{
Léa Luciani ${ }^{1,2}$, Grégory Dubourg ${ }^{1,2}$, Thomas Graillon ${ }^{3}$, Estelle Honnorat ${ }^{4}$, Hubert Lepidi ${ }^{1}$, Michel Drancourt ${ }^{1,2}$, \\ Piseth Seng ${ }^{1,2,4,5^{*}}$ (D) and Andreas Stein ${ }^{1,2,4}$
}

\begin{abstract}
Background: Salmonella brain abscess associated with brain tumor is rare. Only 11 cases have been reported to date. Here we report a case of brain abscess caused by Salmonella enterica serovar Enteritidis mimicking post-surgical meningitis in a patient with glioblastoma multiforme.

Case presentation: A 60-year-old Algerian woman was admitted through an emergency department for a 4-day history of headache, nausea and vomiting, and behavioral disorders. Surgery for cerebral tumor excision was performed and histopathological analysis revealed glioblastoma multiforme. On the seventh day post-surgery, she presented a sudden neurological deterioration with a meningeal syndrome, confusion, and fever of $39.8^{\circ} \mathrm{C}$. Her cerebrospinal fluid sample and blood cultures were positive for S. enterica Enteritidis. She was treated with ceftriaxone and ciprofloxacin. On the 17th day post-surgery, she presented a new neurological disorder and purulent discharge from the surgical wound. Brain computed tomography revealed a large cerebral abscess located at the operative site. Surgical drainage of the abscess was performed and microbial cultures of surgical deep samples were positive for the same S. enterica Enteritidis isolate. She recovered and was discharged 6 weeks after admission.

Conclusions: In this case report, a brain abscess was initially diagnosed as Salmonella post-surgical meningitis before the imaging diagnosis of the brain abscess. The diagnosis of brain abscess should be considered in all cases of non-typhoidal Salmonella meningitis after surgery for brain tumor. Surgical brain abscess drainage followed by prolonged antibiotic treatment remains a major therapeutic option.
\end{abstract}

Keywords: Brain abscess, Glioblastoma, Post-surgery meningitis, Salmonella, Salmonella enterica, MALDI-TOF, Bacteria, Infection, Human

\section{Background}

Salmonella species are mainly known as common agents of gastroenteritis worldwide. Invasive Salmonella infections have been reported due to their potential to cause focal suppurative complications in urinary tract

\footnotetext{
* Correspondence: sengpiseth@yahoo.fr

${ }^{1}$ Aix Marseille Université, URMITE, UM63, CNRS 7278, IRD 198, Inserm 1095, 13005 Marseille, France

²Pôle de Maladies Infectieuses, Hôpital de la Timone, Assistance Publique Hôpitaux de Marseille, Institut Hospitalo-Universitaire Méditerranée Infection, 13005 Marseille, France

Full list of author information is available at the end of the article
}

infection, osteoarticular infection and liver abscess [1]. Central nervous system Salmonella infection is rare and occurs primarily in young children [2] and immunocompromised adults, including human immunodeficiency virus (HIV) infection and co-infected patients [3] and chronic granulomatous disease [4]. Here, we report a case of brain abscess caused by $S$. enterica subspecies (subsp.) enterica serovar Enteritidis mimicking postsurgical meningitis in a patient with glioblastoma multiforme. We also review cases of Salmonella brain abscess in patients with cerebral tumors. 


\section{Case presentation}

In September 2015, a 60-year-old Algerian woman was seen in the emergency department in Marseille, France for a 4-day history of headache, nausea and vomiting, and behavioral disorders. She had an unremarkable medical history apart from obesity (body mass index at $30.9 \mathrm{~kg} /$ $\mathrm{m}^{2}$ ). Brain magnetic resonance imaging (MRI) revealed a single $40 \times 35 \mathrm{~mm}$ tumor in her right mesial temporal region and a mass effect compression of her right lateral ventricle with transtentorial herniation (Fig. 1). She was transferred to our neurosurgery department, where levetiracetam and methylprednisolone led to neurological improvement. At that time, her leukocyte count was elevated at $22 \times 10^{9} / \mathrm{L}$ (neutrophil count was $21 \times 10^{9} / \mathrm{L}$, lymphocytes were decreased at $0.47 \times 10^{9} / \mathrm{L}$, and her platelet count was $291 \times 10^{9} / \mathrm{L}$ ). Surgery for tumor removal was performed on day 5 of her admission. A histological examination revealed glioblastoma multiforme (Fig. 2). No bacteria were seen on histological analysis.

On the seventh day post-surgery, she presented a sudden neurological deterioration with a meningeal syndrome, confusion and fever of $39.8{ }^{\circ} \mathrm{C}$. Laboratory investigations revealed an elevated leukocyte count at $13 \times 10^{9} / \mathrm{L}$, elevated neutrophils at $12.62 \times 10^{9} / \mathrm{L}$, low lymphocytes at $0.15 \times 10^{9} / \mathrm{L}$, normal platelets at $154 \times 10^{9} / \mathrm{L}$, and elevated C-reactive protein at $304 \mathrm{mg} / \mathrm{L}$. Cerebrospinal fluid (CSF) sample analysis revealed an elevated protein level of $2.93 \mathrm{~g} / \mathrm{L}$, a low glucose level of $0.1 \mathrm{mmol} / \mathrm{L}$, and a leukocyte count of 5400 cells/mm3 with $80 \%$ neutrophils. CSF cultures and blood cultures were positive for S. enterica. The isolates from the

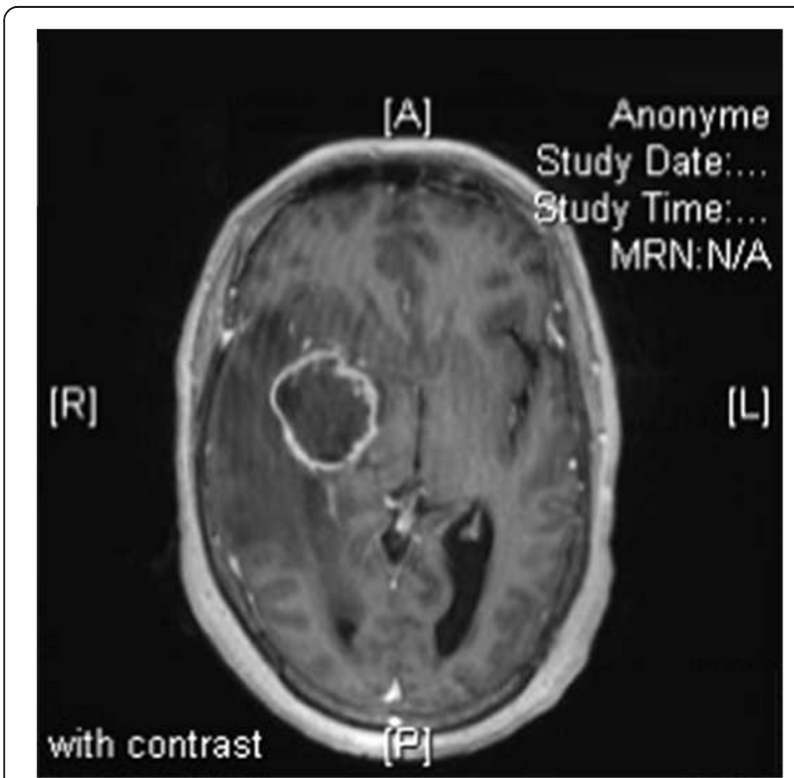

Fig. 1 Brain magnetic resonance imaging revealed a single $40 \times 35 \mathrm{~mm}$ tumor in the right mesial temporal region and a mass effect compression of the right lateral ventricle with transtentorial herniation

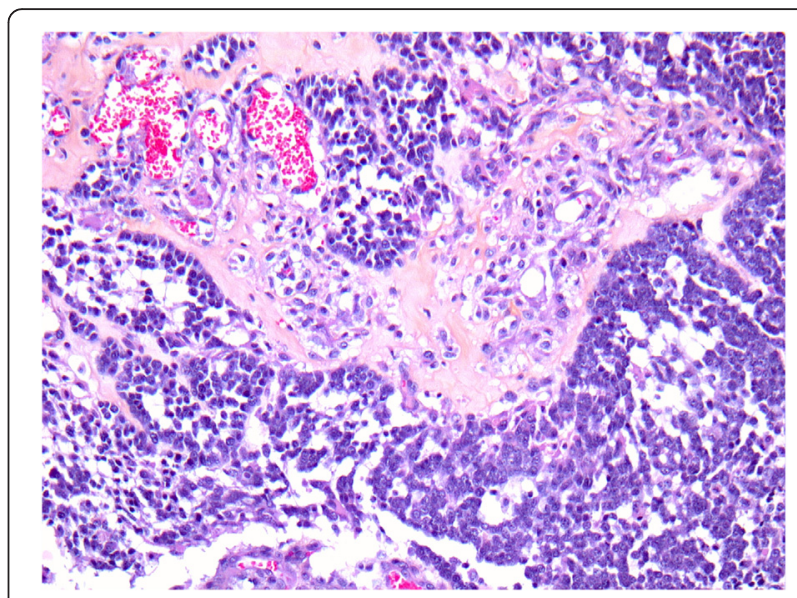

Fig. 2 A histological examination revealed glioblastoma multiforme without any microorganism identified on histological analysis

CSF and blood were further identified as S. enterica subsp. enterica serotype Enteritidis as identified by our national reference center for Salmonella (Institut Pasteur, Paris). The isolates were susceptible in vitro to amoxicillin, ceftriaxone, imipenem/cilastatin, gentamycin, co-trimoxazole and fluoroquinolone.

A diagnosis of Salmonella meningitis was made and she was treated with ceftriaxone administered intravenously $2 \mathrm{~g} /$ day and oral ciprofloxacin $500 \mathrm{mg}$ every 8 hours. On the 17th day post-surgery, she presented a new neurological disorder and purulent discharge from the surgical wound. Brain computed tomography $(\mathrm{CT})$ revealed a large cerebral abscess located at the operative site (Fig. 3). Surgical drainage of the abscess was

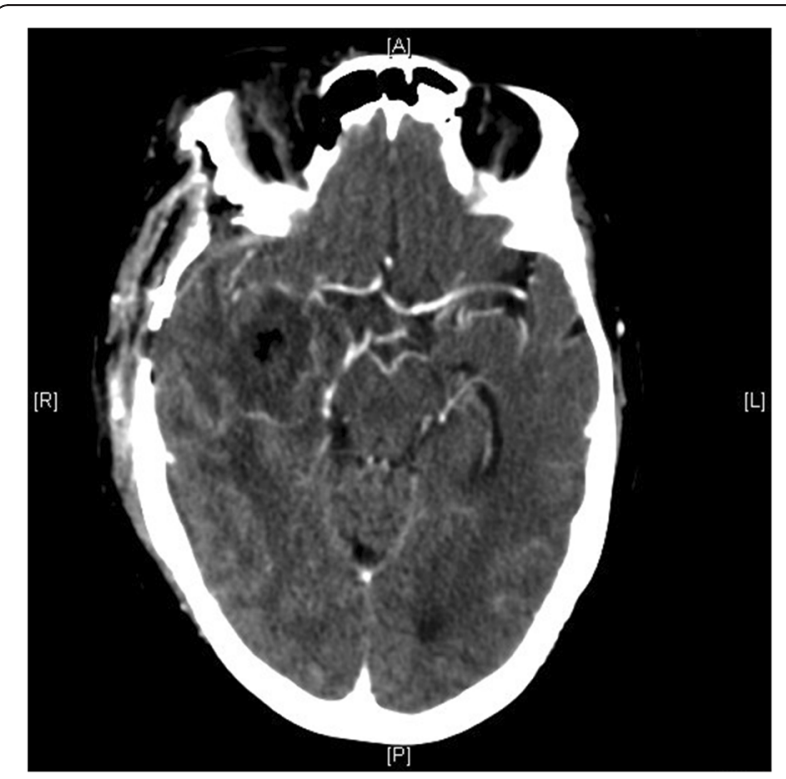

Fig. 3 Computed tomography reveals a large cerebral abscess located at the operative site 
Table 1 Review of 12 cases of Salmonella brain abscess related to brain tumors reported in the literature and in our case

\begin{tabular}{|c|c|c|c|c|c|c|c|c|c|}
\hline Cases & $\begin{array}{l}\text { Age, sex, } \\
\text { geographical } \\
\text { origin }\end{array}$ & Cerebral tumor & $\begin{array}{l}\text { Tumor } \\
\text { surgery } \\
\text { before } \\
\text { diagnosis of } \\
\text { brain } \\
\text { abscess }\end{array}$ & $\begin{array}{l}\text { Patients } \\
\text { under } \\
\text { systemic } \\
\text { corticosteroid } \\
\text { treatment }\end{array}$ & Clinical symptoms & Surgical drainage & $\begin{array}{l}\text { Antibiotic } \\
\text { treatment }\end{array}$ & Salmonella species & $\begin{array}{l}\text { Clinical } \\
\text { outcome }\end{array}$ \\
\hline Our case (2015) & $\begin{array}{l}60 \text { years, female, } \\
\text { Algeria }\end{array}$ & $\begin{array}{l}\text { Yes, multiforme } \\
\text { glioblastoma }\end{array}$ & Yes & Yes & $\begin{array}{l}\text { Sudden neurological } \\
\text { deterioration, meningeal } \\
\text { syndrome }\end{array}$ & Yes & Yes, 3 months & $\begin{array}{l}\text { Salmonella Enteritidis } \\
\text { (CSF, blood, pus, brain } \\
\text { abscess) }\end{array}$ & Good \\
\hline $\begin{array}{l}\text { Rodriguez, Valero, and } \\
\text { Watanakunakorn } 1986 \text { [8] }\end{array}$ & $\begin{array}{l}28 \text { years, male, } \\
\text { Ohio (USA) }\end{array}$ & $\begin{array}{l}\text { Yes, metastatic } \\
\text { carcinoma }\end{array}$ & No & Yes & $\begin{array}{l}\text { Per orbital pain, nausea, } \\
\text { papilledema }\end{array}$ & Yes & $\begin{array}{l}\text { Yes, } 6 \text { weeks } \\
\text { (radiotherapy) }\end{array}$ & $\begin{array}{l}\text { Salmonella Enteritidis } \\
\text { (brain tissue and } \\
\text { blood) }\end{array}$ & Good \\
\hline $\begin{array}{l}\text { Sharma, Raja, and } \\
\text { Shivananda } 1986 \text { [9] }\end{array}$ & $\begin{array}{l}32 \text { years, male, } \\
\text { India }\end{array}$ & $\begin{array}{l}\text { Yes, malignant } \\
\text { astrocytoma }\end{array}$ & Yes & No & $\begin{array}{l}\text { Headache, vomiting, } \\
\text { somnolence }\end{array}$ & Yes & $\begin{array}{l}\text { Yes, unknown } \\
\text { duration }\end{array}$ & Salmonella Typhi & Good \\
\hline Noguerado et al. 1987 [10] & $\begin{array}{l}78 \text { years, male, } \\
\text { Spain }\end{array}$ & $\begin{array}{l}\text { Yes, multiforme } \\
\text { glioblastoma }\end{array}$ & No & Yes & $\begin{array}{l}\text { General conditions } \\
\text { deteriorated, fever, } \\
\text { meningeal syndrome, } \\
\text { septic shock }\end{array}$ & No & Yes & $\begin{array}{l}\text { Salmonella Enteritidis } \\
\text { (CSF and blood) }\end{array}$ & Died \\
\hline Bossi et al. 1993 [11] & $\begin{array}{l}24 \text { years, male, } \\
\text { Tunisia }\end{array}$ & $\begin{array}{l}\text { Yes, multiforme } \\
\text { glioblastoma }\end{array}$ & Yes & Yes & Fever, confusion & Yes & $\begin{array}{l}\text { Yes, unknown } \\
\text { duration }\end{array}$ & $\begin{array}{l}\text { Salmonella Enteritidis } \\
\text { (CSF, blood and brain } \\
\text { abscess) }\end{array}$ & Good \\
\hline $\begin{array}{l}\text { Shanley and Holmes } \\
1994 \text { [12] }\end{array}$ & $\begin{array}{l}28 \text { years, female, } \\
\text { Hawaii (USA) }\end{array}$ & $\begin{array}{l}\text { Yes, } \\
\text { craniopharyngioma }\end{array}$ & No & $\begin{array}{l}\text { Not } \\
\text { mentioned }\end{array}$ & Sudden loss of vision & $\begin{array}{l}\text { Yes, } \\
\text { Hypophysectomy } \\
\text { to decompress } \\
\text { optic chiasm }\end{array}$ & Not mentioned & $\begin{array}{l}\text { Salmonella Typhi (pus, } \\
\text { brain abscess) }\end{array}$ & Good \\
\hline Fiteni et al. 1995 [13] & $\begin{array}{l}49 \text { years, female, } \\
\text { France }\end{array}$ & Yes, astrocytoma & Yes & Yes & Fever, confusion & Yes & Yes, 9 weeks & $\begin{array}{l}\text { Salmonella Enteritidis } \\
\text { (CSF, blood and brain } \\
\text { abscess) }\end{array}$ & $\begin{array}{l}\text { Residual } \\
\text { hemiparesis }\end{array}$ \\
\hline $\begin{array}{l}\text { Sarria, Vidal, and } \\
\text { Kimbrough lii } 2000 \text { [14] }\end{array}$ & $\begin{array}{l}58 \text { years, female, } \\
\text { Texas (USA) }\end{array}$ & $\begin{array}{l}\text { Yes, multiforme } \\
\text { glioblastoma }\end{array}$ & No & Yes & $\begin{array}{l}\text { Fever, meningeal } \\
\text { syndrome, hemiparesis, } \\
\text { coma }\end{array}$ & Yes & $\begin{array}{l}\text { Yes, } 6 \text { weeks } \\
\text { and local } \\
\text { application }\end{array}$ & $\begin{array}{l}\text { Salmonella Enteritidis } \\
\text { (material) }\end{array}$ & Died \\
\hline Kumari and Kan 2000 [15] & $\begin{array}{l}59 \text { years, male, } \\
\text { Washington } \\
\text { (USA) }\end{array}$ & $\begin{array}{l}\text { Yes, metastatic } \\
\text { adenocarcinoma }\end{array}$ & Yes & Yes & $\begin{array}{l}\text { Fever, tachycardia, } \\
\text { confusion }\end{array}$ & Yes & Yes, 6 weeks & $\begin{array}{l}\text { Salmonella typhimurium } \\
\text { (cerebral abscess) }\end{array}$ & Good \\
\hline Schröder et al. 2003 [16] & $\begin{array}{l}46 \text { years, female, } \\
\text { Germany }\end{array}$ & $\begin{array}{l}\text { Yes, } \\
\text { craniopharyngioma }\end{array}$ & Yes & Yes & $\begin{array}{l}\text { Tension, headache at } \\
\text { craniotomy site }\end{array}$ & Yes & $\begin{array}{l}\text { Yes, duration } \\
\text { not known }\end{array}$ & $\begin{array}{l}\text { Salmonella Enteritidis } \\
\text { (pus, brain abscess) }\end{array}$ & $\begin{array}{l}\text { Coxitis } \\
\text { abscess }\end{array}$ \\
\hline Aissaoui et al. 2006 [17] & $\begin{array}{l}72 \text { years, male, } \\
\text { Morocco }\end{array}$ & $\begin{array}{l}\text { Yes, } \\
\text { oligodendroglioma }\end{array}$ & Yes & Yes & $\begin{array}{l}\text { Fever, neurological } \\
\text { deterioration }\end{array}$ & No & $\begin{array}{l}\text { Yes, } 8 \text { days then } \\
\text { patient died }\end{array}$ & $\begin{array}{l}\text { Salmonella Enteritidis } \\
\text { (CSF and blood) }\end{array}$ & Died \\
\hline Sait et al. 2011 [18] & $\begin{array}{l}57 \text { years, male, } \\
\text { not known }\end{array}$ & $\begin{array}{l}\text { Yes, multiforme } \\
\text { glioblastoma }\end{array}$ & Yes & No & $\begin{array}{l}\text { Headache, discharge } \\
\text { wound, meningeal signs }\end{array}$ & Yes & Yes, 4 weeks & $\begin{array}{l}\text { Salmonella Enteritidis } \\
\text { (material and blood) }\end{array}$ & Good \\
\hline
\end{tabular}


performed by craniotomy, which confirmed the diagnosis of intraparenchymal abscess located at the glioblastoma resection site. Microbial cultures of surgical deep samples were positive for S. enterica subsp. enterica serovar Enteritidis, which were susceptible to all antibiotics tested above. She was discharged 6 weeks after admission. Prolonged 10-day anaerobic bacterial cultures of her CSF, bloodstream and brain abscess were negative. A combination of ceftriaxone-ciprofloxacin was given for 6 weeks, and ciprofloxacin treatment was prolonged for 3 months because of the infectious risk due to chemotherapy immunosuppression. No neurological sequelae were noted. Evaluation of the immune system remained normal and HIV serology was negative.

\section{Discussion}

Here we report a case of brain abscess due to S. enterica subsp. enterica serovar Enteritidis mimicking meningitis occurring after surgery for glioblastoma. Salmonella brain abscesses are rarely reported. Only a few cases of typhoidal Salmonella brain abscess have been reported in immunocompetent adults, usually related to situations promoting their incidence, including recent travel in endemic areas [5], typhoid fever [6], or ingestion of contaminated milk [7]. To the best of our knowledge, only 11 cases of Salmonella brain abscess associated with brain tumor have been reported [8-18]. Most of these cases (nine cases) were caused by non-typhoidal Salmonella, including eight cases of S. enterica Enteritidis and one case of Salmonella enterica Typhimurium. However, S. enterica Typhimurium is usually responsible for invasive human salmonellosis [19]. Glioblastoma is the main type of brain tumor that has been associated with Salmonella brain abscess (four cases), and all of these cases were caused by $S$. enterica Enteritidis (Table 1).

Symptoms of Salmonella brain abscess associated with brain tumor are heterogeneous. Most cases (six cases) have occurred after surgical resection of a brain tumor, initially indicated by fever or neurological deterioration and confusion. However, meningeal signs were noted in three reported cases. In our case, the brain abscess was initially diagnosed as Salmonella post-surgical meningitis before imaging diagnosis of the brain abscess. In our case, the diagnosis of glioblastoma multiforme was suggested by brain MRI and confirmed by a histological examination of the surgical biopsy. In vivo imaging technology, such as molecular imaging, is useful in the diagnosis of brain tumors [20] and might be helpful to differentiate bacterial abscess from tumoral tissues and underlying primary disease [21].

In the literature, Salmonella species have been identified in purulent exudates from brain abscesses (six cases) and in blood cultures (six cases) and CSF cultures (four cases). In our case, Salmonella isolates were identified in the blood, CSF and brain abscess. Most cases in the literature were treated with systemic corticosteroids for brain tumor (eight cases) when the Salmonella brain abscess was diagnosed. The prognosis is relatively good with antibiotic treatment. There is no comparative study on the use of dual antibiotic therapy rather than single antibiotic for this indication. Nevertheless, we decided to treat our case initially with a 6-week combination of ceftriaxone-ciprofloxacin due to a significant risk of immunosuppression related to treatment of the glioblastoma multiforme and the large brain abscess. The duration of antibiotic treatment in the literature varied from 4 weeks to 3 months. Most cases in the literature (nine cases) were treated surgically for the brain abscess. However, three patients died and two patients had complications, including residual hemiparesis in one case and a hip abscess in one case.

Chronic carriage of Salmonella, primarily biliary, may persist after infection (about $1 \%$ of cases) [22]. In our case, septic signs and digestive symptoms such as gastroenteritis were absent on admission and the clinical symptoms of brain abscess such as fever, meningeal signs, and neurological deterioration occurred only at 1 week post-surgery for glioblastoma. These phenomena might be explained by Salmonella's tropism for necrotic tissue [23], and the central nervous system infection could be secondary to blood dissemination of Salmonella from digestive reservoirs in the bile or intestine. Unfortunately, this hypothesis is difficult to confirm due to the transitory carriage and because a stool culture had unfortunately not been performed.

\section{Conclusions}

Salmonella brain abscess is rare but can occur in apparently immunocompetent adult patients with brain tumor. The diagnosis of brain abscess should be considered in all cases of non-typhoid Salmonella meningitis after surgery for brain tumor. Prolonged antibiotic treatment after surgical brain abscess drainage remains a major therapeutic option.

\footnotetext{
Acknowledgements

We thank the house officers and medical staff for their confidence in our management of the patient.

The authors have no relevant affiliations or financial involvement with any organization or entity with a financial interest in or financial conflict with the subject matter or materials discussed in the manuscript. No assistance was utilized in the writing of this manuscript.
}

Availability of data and supporting materials

Medical imaging data will not be shared because it is not fully anonymous

Authors' contributions

LL: 1st author, clinical data collection; he was involved in drafting the manuscript. GD: 2nd author, microbiological data collection, manuscript revision. TG: 3rd author, clinical data verification and manuscript revision. $\mathrm{EH}$ : 4th author; surgical data verification and manuscript revision. HL: 5th 
author, histological analysis, manuscript revision, and discussion section. MD: 6th author, microbiological data verification and manuscript revision. PS: first final author and corresponding author; he made substantial contributions to study conception and design, clinical data verification, discussion section, and manuscript revision. AS: second final author, clinical data verification, discussion section, and final approval of the version to be published. All authors read and approved the final manuscript.

\section{Competing interests}

The authors declare that they have no competing interests.

\section{Consent for publication}

Written informed consent was obtained from the patient for publication of this case report and any accompanying images. A copy of the written consent is available for review by the Editor-in-Chief of this journal.

\section{Author details}

Aix Marseille Université, URMITE, UM63, CNRS 7278, IRD 198, Inserm 1095, 13005 Marseille, France. ${ }^{2}$ Pôle de Maladies Infectieuses, Hôpital de la Timone, Assistance Publique Hôpitaux de Marseille, Institut Hospitalo-Universitaire Méditerranée Infection, 13005 Marseille, France. ${ }^{3}$ Service de neurochirurgie, Hôpital de la Timone, Assistance Publique Hôpitaux de Marseille, 13005 Marseille, France. ${ }^{4}$ Service des Maladies Infectieuses, Hôpital de la Conception, 147, boulevard Baille, 13005 Marseille, France. ${ }^{5}$ Unité de Recherche sur les Maladies Infectieuses et Tropicales Emergentes, Faculté de Médecine, Aix Marseille Université, 27, Boulevard Jean Moulin, 13385 Marseille, Cedex 5, France.

Received: 9 March 2016 Accepted: 3 June 2016

Published online: 07 July 2016

\section{References}

1. Wilkins EGL, Roberts C. Extraintestinal salmonellosis. Epidemiol Infect. 1988; 100:361-8.

2. Murphy D, Oshin F. Reptile-associated salmonellosis in children aged under 5 years in South West England. Arch Dis Child. 2015;100:364-5.

3. Aliaga L, Mediavilla JD, López de la Osa A, Melander E, López-Gómez M, de Cueto M, et al. Nontyphoidal Salmonella Intracranial Infections in HIVInfected Patients. Clin Infect Dis. 1997;25:1118-20.

4. Ma J-S, Chen P-Y, Lau Y-J, Chi C-S. Brain abscess caused by Salmonella enterica subspecies houtenae in a patient with chronic granulomatous disease. $J$ Microbiol Immunol Infect Wei Mian Yu Gan Ran Za Zhi. 2003;36:282-4.

5. Bonvin P, Ejlertsen T, Dons-Jensen H. Brain Abscess Caused by Salmonella enteritidis in an Immunocompetent Adult Patient: Successful Treatment with Cefotaxime and Ciprofloxacin. Scand J Infect Dis. 1998;30:632-3.

6. Suzuki Y, Sugiyama Y, Ishii R, Sato I. Brain abscess caused by Salmonella typhi. J Neurosurg. 1976;45:709-11.

7. Ellis ME, Smith CC, Reid TM, Porter IA. Chloramphenicol-resistant Salmonella typhimurium meningitis in an adult. Br Med J (Clin Res Ed). 1981;283:273.

8. Rodriguez RE, Valero V, Watanakunakorn C. Salmonella focal intracranial infections: review of the world literature (1884-1984) and report of an unusual case. Rev Infect Dis. 1986;8:31-41.

9. Sharma S, Raja A, Shivananda PG. Isolation of Salmonella typhi from brain tumor-a case report. Indian J Med Sci. 1986;40:233-5.

10. Noguerado A, Cabanyes J, Vivancos J, Navarro E, Lopez F, Isasia T, et al. Abscess caused by Salmonella enteritidis within a glioblastoma multiforme. J Infect. 1987:15:61-3.

11. Bossi P, Mion G, Brinquin L, Bonsignour JP. [Postoperative brain abscess caused by Salmonella enteritidis]. Presse Médicale Paris Fr 1983. 1993:22:130.

12. Shanley DJ, Holmes SM. Salmonella typhi abscess in a craniopharyngioma: CT and MRI. Neuroradiology. 1994;36:35-6.

13. Fiteni I, Ruiz FJ, Crusells MJ, Sanjoaquin I, Guillen G. [Salmonella enteritidis multifocal infection of the central nervous system. Efficacy of new cephalosporins]. Presse Médicale Paris Fr 1983. 1995:24:309-11.

14. Sarria JC, Vidal AM, Kimbrough III RC. Salmonella enteritidis brain abscess: case report and review. Clin Neurol Neurosurg. 2000;102:236-9.

15. Kumari P, Kan VL. Salmonella typhimurium Brain Abscess: Postoperative Complication. Clin Infect Dis. 2000;30:621-2.

16. Schröder J, Palkovic S, Kipp F, Wassmann H. Salmonella enteritidis causing brain abscess and coxitis following intracranial surgery. Acta Neurochir (Wien). 2003;145:919-21.
17. Aissaoui Y, Azendour H, Balkhi H, Haimeur C, Atmani M. [Postoperative meningitis caused by an unusual etiological agent: Salmonella enteritidis] Neurochirurgie. 2006;52:547-50.

18. Sait M, Rahmathulla G, Chen $T L$, Barnett $G H$. Rare case of intracranial Salmonella enteritidis abscess following glioblastoma resection: Case report and review of the literature. Surg Neurol Int [Internet]. 2011[cited 2015 Nov 29]; 2. Available from: http://www.ncbi.nlm.nih.gov/pmc/articles/PMC3205504/.

19. Kwambana-Adams B, Darboe S, Nabwera H, Foster-Nyarko E, Ikumapayi UN, Secka O, et al. Salmonella Infections in The Gambia, 2005-2015. Clin Infect Dis Off Publ Infect Dis Soc Am. 2015;61 Suppl 4:S354-362.

20. Schaller BJ, Modo M, Buchfelder M. Molecular Imaging of Brain Tumors: A Bridge Between Clinical and Molecular Medicine? Mol Imaging Biol. 2007;9:60-71.

21. Tewari A, Padma S, Sundaram PS. The diagnostic role of 18 fluorodeoxyglucocose-positron emission tomography/computed tomography in occult bacteremia searching underlying primary disease. Ann Indian Acad Neurol. 2012;15:336-8.

22. Buchwald DS, Blaser MJ. A Review of Human Salmonellosis: II. Duration of Excretion Following Infection with Nontyphi Salmonella. Rev Infect Dis. 1984;6:345-56.

23. Forbes NS. Engineering the perfect (bacterial) cancer therapy. Nat Rev Cancer. 2010:10:785-94.

\section{Submit your next manuscript to BioMed Central and we will help you at every step:}

- We accept pre-submission inquiries

- Our selector tool helps you to find the most relevant journal

- We provide round the clock customer support

- Convenient online submission

- Thorough peer review

- Inclusion in PubMed and all major indexing services

- Maximum visibility for your research

Submit your manuscript at www.biomedcentral.com/submit 